\section{PELATIHAN \\ PENYELESAIAN SOAL- \\ SOAL STRUCTURE AND \\ WRITTEN EXPRESSION \\ BEREKUIVALENSI TOEFL \\ PADA SISWA SMK \\ TELKOM PEKANBARU}

Qori Islami Aris', Essy Syam²

1,2Universitas Lancang Kuning

*Qori Islami Aris

Email : qoriislamibintiaris@unilak.ac.id

\begin{abstract}
In this program, the community service team will provide strategies or tips in solving each problem in the Structure and Written Expression session. Therefore, this program is considered very necessary to make $a$ valuable contribution to the community, especially the students of SMK Telkom Pekanbaru. The stages carried out in the training process to complete Structure and Written Expression questions, among others: (I) The preparation stage for training activities. At this stage, community service activities regarding training for the completion of Structure and Written Expression questions for students of SMK Telkom Pekanbaru. (2) The training phases. At this stage, students are tested for their skills in mastering the Structure and Written Expression questions.

Keywords: TOEFL-TEST; Structure and Written Expression
\end{abstract}

\begin{abstract}
Abstrak
Dalam kegiatan ini, tim pengabdian kepada masyarakat akan memberikan strategi-strategi atau tips-tips dalam memecahkan setiap soal dalam sesi Structure and Written Expression tersebut. Oleh karena itu, program ini dinilai sangat diperlukan sebagai upaya untuk memerikan sumbangan yang bermanfaat bagi masyarakat, khususnya para siswa SMK Telkom Pekanbaru. Tahap-tahap yang dilaksanakan dalam proses pelatihan penyelesaian soalsoal Structure and Written Expression Berekuivalensi TOEFL, antara lain (I)Tahap Persiapan kegiatan pelatihan, pada tahap ini kegiatan pengabdian kepada masyarakat tentang pelatihan penyelesaian soal-soal Structure and Written Expression Berekuivalensi TOEFL untuk siswa-siswa SMK Telkom meliputi beberapa proses termasuk pengenalan, pemahaman latihan awal dan diskusi (2)Tahap pelatihan, pada tahap ini siswa diuji keterampilannya dalam penguasaan penyelesaian soal-soal Structure and Written Expression Berekuivalensi TOEFL.

Kata Kunci: TOEFL TEST; Structure and Written Expression
\end{abstract}


Pelatihan Penyelesaian Soal-Soal Structure dan Written Expression Berekuivalensi TOEFL pada Siswa SMK Telkom Pekanbaru

Qori Islami Aris, Essy Syam

Vol. 1, No. 2, Agustus 2021 hal. 109-115

DOI Artikel : 10.46306/jub.v1i2.21

\section{PENDAHULUAN}

Di dalam TOEFL, terdapat 3 kompetensi, yaitu; Listening, Structure and Written Expression, dan Reading Comprehension. Semua materi diadopsi dari buku Deborah Philip. Dalam pengabdian ini, tim pengabdian fokus kepada satu elemen yakni Structure and Written Expression yang merupakan kemampuan dasar dalam memahami Bahasa Inggris sesuai dengan tatabahasa yang benar.

Selain itu, secara akademik, tujuan menggunakan tes ini untuk tujuan pendidikan, penelitian, dan/atau yang berhubungan dengan kegiatan akademis lainnya di dalam negeri maupun luar negeri, misalnya untuk melanjutkan ke jenjang perguruan tinggi sarjana, magister maupun doktor baik di dalam maupun luar negeri. Tujuan umumnya yaitu tujuan pekerjaan, kenaikan pangkat, dan lain sebagainya.

Berangkat dari urgensi situasi di atas, maka pelatihan ini dinilai sangat diperlukan khususnya bagi siswa sekolah menengah atas ataupun kejuruan yang akan menempuh pendidikan perguruan tinggi ataupun menghadapi dunia kerja. Dalam kegiatan pengabdian yang akan diselenggarakan ini, materi dalam tes TOEFL yang akan diajarkan dalam pelatihan yaitu Structure and Written Expression yang bertujuan untuk menguji kemampuan dalam mengidentifikasi bahasa Inggris tulis yang digunakan dalam situasi formal (formal written English). Banyak ekspresi-ekspresi bahasa Inggris yang bisa diterima dalam komunikasi lisan, namun tidak bisa diterima atau tidak lazim digunakan dalam komunikasi tulis, apalagi yang bersifat formal. Soal-soal pada sesi Structure and Written Expression ini terdiri dari dua bagian, struktur kalimat (structure) dan ekspresi bahasa Inggris tulis (written expression). Structure and Written Expression terdiri dari 40 soal, terdiri dari 15 soal structure (nomor I sampai dengan 15) dan 25 soal untuk written expression (nomor 16 sampai dengan 40). Waktu untuk mengerjakan 40 soal ini adalah 25 menit.

Dalam kegiatan ini, tim pengabdian kepada masyarakat akan memberikan strategi-strategi atau tipstips dalam memecahkan setiap soal dalam sesi Structure and Written Expression tersebut. Oleh karena itu, program ini dinilai sangat diperlukan sebagai upaya untuk memberikan sumbangan yang bermanfaat bagi masyarakat, khususnya para siswa SMK Telkom Pekanbaru.

Berdasarkan analisis situasi yang telah dipaparkan di atas, dirumuskan beberapa permasalahan mitra, antara lain:

I. Pengetahuan siswa mengenai TOEFL-Test masih rendah

2. Keterampilan Bahasa Inggris pada Structure and Written Expression siswa masih rendah.

Berbeda dengan SMA yang diprogram untuk melanjutkan ke tingkat pendidikan yang lebih tinggi, SMK pada dasarnya disiapkan untuk mampu bersaing di dunia kerja dan dapat menciptakan lapangan kerja sendiri yang dibuktikan dengan sajian kurikulum yang memiliki bobot $70 \%$ untuk keterampilan dan $30 \%$ untuk teori. Ini berarti bahwa lulusan SMK dituntut untuk mampu bersaing dalam dunia kerja dan dapat menciptakan lapangan kerja sendiri.

Oleh karena itu, menurut permasalahan di atas, yang menuntut bagaimana siswa SMK mampu menghasilkan siswa yang terampil serta siap bersaing dalam dunia kerja setelah mereka tamat, maka tim pengabdian bekerjasama dengan pihak sekolah untuk melaksanakan pelatihan ini. Salah satunya adalah meningkatkan sumber daya manusia yaitu meningkatkan penguasaan Bahasa Inggris para siswa SMK Telkom Pekanbaru, karena perusahaan-perusahaan yang ada saat ini mencantumkan persyaratan kemampuan berbahasa Inggris sebagai salah satu syarat untuk menjadi karyawan di perusahaan tersebut. 
Pelatihan Penyelesaian Soal-Soal Structure dan Written Expression Berekuivalensi TOEFL pada Siswa SMK Telkom Pekanbaru

Qori Islami Aris, Essy Syam

Vol. 1, No. 2, Agustus 2021 hal. 109-115

DOI Artikel : 10.46306/jub.v1i2.21

\section{METODE PENGABDIAN}

Kegiatan I $\mathrm{b}$ dilakukan kepada pelajar SMK Telkom Pekanbaru. Jumlah pelajar yang akan mengikuti pelatihan ini berjumlah 16 orang. Pelaksanaan kegiatan meliputi beberapa tahap sebagai berikut.

I. Penyelesaian Soal Mandiri (Pre-test)

Pada sesi ini, siswa diarahkan untuk mengerjakan 10 butir soal pilihan ganda untuk mencari jawaban yang tepat. Mereka diberikan waktu setengah jam untuk menyelesaikan soal-soal tersebut.

2. Ceramah

Pada sesi ini, tim pengabdian memaparkan materi inti yang dipelajari berkaitan dengan Structure and Written Expression. Materi initi meliputi lima keterampilan dasar dalam menyelesaiakn soal-soal Stucture and Written Expression, antara lain: Subject-Verb Agreement, Object of Preposition, Appositive, Present Participle, dan Past Participle. Selain itu, tim pengabdian juga memaparkan tips-tips dan strategi-strategi dalam menyelesaikan soal-soal yang disajikan. Pada setiap pertemuannya kegiatan ceramah ini dialokasikan selama 2 jam.

3. Diskusi

Pada sesi ini, tim pengabdian memfasilitasi siswa untuk bertanya jika masih menemukan materi yang kurang dipahami sehingga harapannya bisa meningkatkan gairah belajar dan rasa ingin tahu mereka.

4. Latihan

Kegiatan ini dilaksanakan guna mengetahui sejauh mana siswa memahami materi yang disampaikan, latihan ini akan dilakukan setelah siswa memperoleh materi inti. Dilakukan secara berkala pada setiap topik bahasan. Dan setiap sesi akan ada pembahasan soal-soal tersebut sehingga para siswa bisa mengetahui hasil pekerjaan mereka.

5. Post-test

Tahapan evaluasi terakhir yang mengukur pemahaman siswa secara komprehensif. Tahapan ini digunakan juga untuk menarik kesimpulan atas kegiatan pengabdian yang telah dilaksanakan.

\section{PELAKSANAAN DAN PEMBAHASAN}

Kegiatan pengabdian ini dilaksanakan pada 23 Juni 202 I pada siswa SMK Telkom Pekanbaru yang berjumlah 16 orang. Kegiatan ini dilaksanakan dalam bentuk pelatihan dalam rangka memberikan pemahaman tentang pelatihan penyelesaian soal-soal berekuivalensi TOEFL. Kegiatan pengabdian tersebut berjalan dengan lancar dan kondusif dan para peserta sangat antusias mengikuti kegiatan tersebut.

Sebelum melaksanakan kegiatan pengabdian ini, tim pengabdian melakukan analisis situasi demi memenuhi kebutuhan di lapangan. Kegiatan ini dilakukan dengan cara berdiskusi dengan pihak sekolah yang dalam hal ini sebagai mitra dan observasi singkat terkait pengetahuan dan kemampuan siswa dalam memahami apa itu TOEFL. Setelah tim pengabdian melakukan analisis situasi dan observasi singkat, mitra sangat menyambut baik kegiatan ini yang dibuktikan dengan kesediaannya menyiapkan tempat dan fasilitas lainnya serta menjadi penanggung jawab kegiatan pengabdian sehingga kegiatan ini berjalan dengan lancar dan kondusif.

Pelaksanaan kegiatan pengabdian kepada masyarakat ini dilakukan dengan beberapa tahapan, antara lain:

I) Persiapan Kegiatan Pelatihan

Persiapan kegiatan pengabdian kepada masyarakat tentang pelatihan penyelesaian soal-soal Structure and Written Expression Berekuivalensi TOEFL untuk siswa-siswa SMK Telkom meliputi beberapa tahapan sebagai berikut:

a. Pemilihan topik kegiatan pengabdian kepada masyarakat tentang soal-soal Structure and Written Espression Berekuivalensi TOEFL. 
Pelatihan Penyelesaian Soal-Soal Structure dan Written Expression Berekuivalensi TOEFL pada Siswa SMK Telkom Pekanbaru

Qori Islami Aris, Essy Syam

Vol. 1, No. 2, Agustus 2021 hal. 109-115

DOI Artikel : 10.46306/jub.v1i2.21

b. Pengaturan waktu (time schedule) pelatihan yang ditentukan seminggu sebelum kegiatan pengabdian dilaksanakan yakni tanggal 23 Juni 202 I dan terbagi dalam 2 sesi, yakni sesi pertama Pukul 10.00-12.00 WIB dan sesi kedua Pukul I3.00 - 16.00 WIB.

c. Pembuatan soal-soal untuk Pretest

d. Persiapan alat dan bahan materi pelatihan dalam bentuk Powerpoint (PPT)

e. Memberikan pelayanan dan pemahaman mengenai soal-soal Structure and Written Expression Berekuivalensi TOEFL pada siswa-siswa SMK Telkom.

2) Tahap Pelatihan

Bentuk kegiatan yang telah dilaksanakan dalam pengabdian kepada masyarakat "Pelatihan Penyelesaian Soal-Soal Structure and Written Expression Berekuivalensi TOEFL pada Siswa SMK Telkom Pekanbaru" adalah metode ceramah dan diskusi.

Kegiatan dibagi 2 sesi, sesi pertama dilaksanakan test awal pada Pukul 10.00 - 12.00 WIB adalah berupa pemberian soal-soal Structure and Written Expression Berekuivalensi TOEFL. Kemampuan awal siswa dapat dilihat dari tabel berikut:

Tabel 2. Hasil Pretest

\begin{tabular}{|c|c|c|c|c|c|}
\hline \multirow{2}{*}{ No. } & \multirow{2}{*}{ Siswa } & \multicolumn{4}{|c|}{ Jawaban Siswa } \\
\hline & & Benar & $\%$ & Salah & $\%$ \\
\hline I & Bunga Ramadani & 5 & $50 \%$ & 5 & $50 \%$ \\
\hline 2 & Dewi Ratna Sari & 5 & $50 \%$ & 5 & $50 \%$ \\
\hline 3 & Wafiq Azizah Putri & 5 & $50 \%$ & 5 & $50 \%$ \\
\hline 4 & Alya Rohalidini & 6 & $60 \%$ & 4 & $40 \%$ \\
\hline 5 & Jingga Lestari & 4 & $40 \%$ & 6 & $60 \%$ \\
\hline 6 & M. Ilham Maulana & 6 & $60 \%$ & 4 & $40 \%$ \\
\hline 7 & Teguh Afrinaldo & 4 & $40 \%$ & 6 & $60 \%$ \\
\hline 8 & Dio Wahyu & 6 & $60 \%$ & 4 & $40 \%$ \\
\hline 9 & Arip Mustofa & 5 & $50 \%$ & 5 & $50 \%$ \\
\hline 10 & Muhammad Alfian & 5 & $50 \%$ & 5 & $50 \%$ \\
\hline II & Nadia Tul Ullia & 6 & $60 \%$ & 4 & $40 \%$ \\
\hline 12 & Ariyan Pagera & 5 & $50 \%$ & 5 & $50 \%$ \\
\hline 13 & Rahma Ayu Vadylla & 5 & $50 \%$ & 5 & $50 \%$ \\
\hline 14 & Febrian Diyas & 4 & $40 \%$ & 6 & $60 \%$ \\
\hline 15 & Irma Gustini & 5 & $50 \%$ & 5 & $50 \%$ \\
\hline 16 & Sofi Adelia Putri & 6 & $60 \%$ & 4 & $40 \%$ \\
\hline \multicolumn{2}{|c|}{ Rata-Rata } & \multicolumn{2}{|c|}{$51 \%$} & \multicolumn{2}{|c|}{$49 \%$} \\
\hline
\end{tabular}

Sesi kedua dilaksanakan pada Pukul 13.00 - 16.00 WIB berupa pelatihan penyelesaian soal-soal Structure and Written Expression Berekuivalensi TOEFL. Dalam sesi ini, juga dikemukakan beberapa tips dan strategi dalam menyelesaikan soal-soal tersebut.

Berikut beberapa bukti foto kegiatan pengabdian kepada masyarakat:

Gambar I. Siswa sedang melaksanakan Pretest

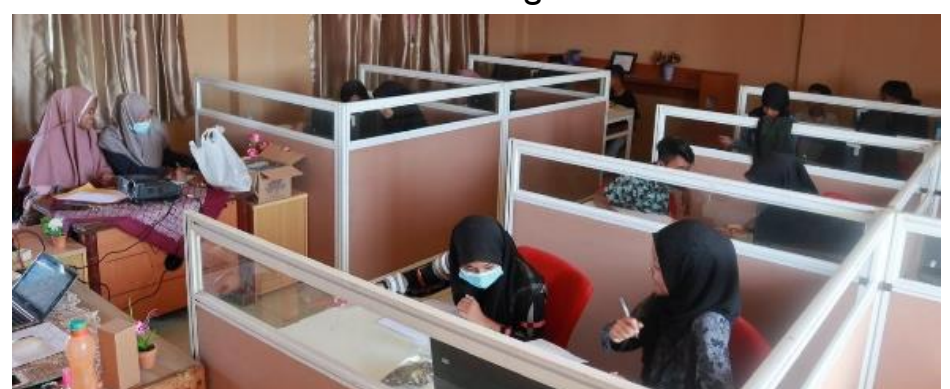


Pelatihan Penyelesaian Soal-Soal Structure dan Written Expression Berekuivalensi TOEFL pada Siswa SMK Telkom Pekanbaru

Qori Islami Aris, Essy Syam

Vol. 1, No. 2, Agustus 2021 hal. 109-115

DOI Artikel : 10.46306/jub.v1i2.21

Gambar 2. Salah seorang Tim IbM memberikan pelatihan

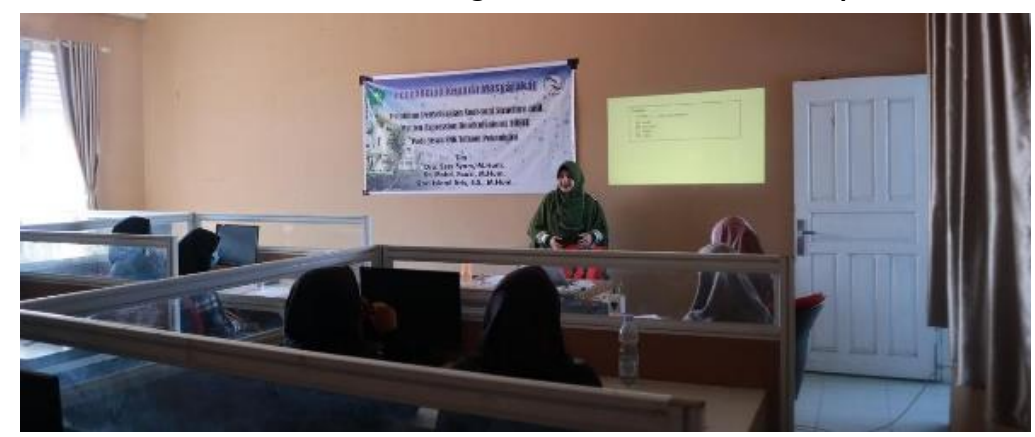

Gambar 3. Foto bersama di akhir kegiatan pengabdian

Pelaksanaan

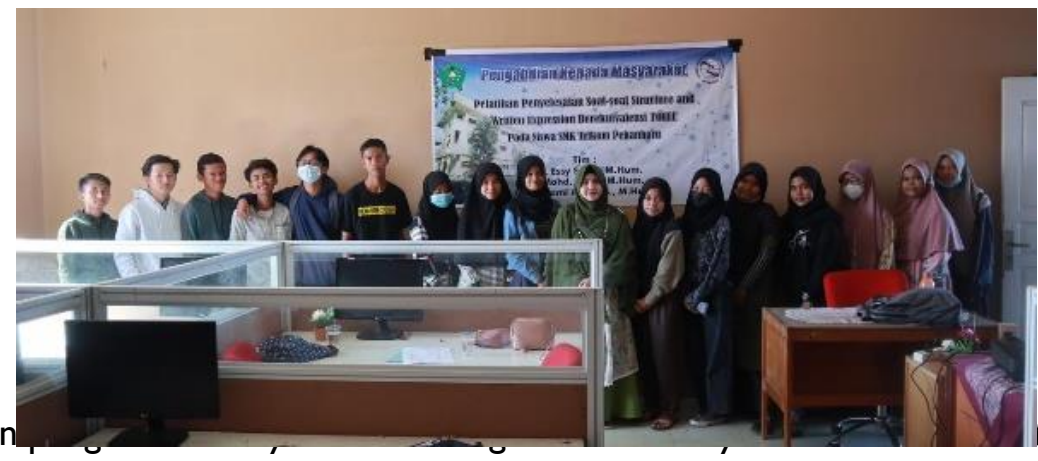

Expression Berekuivalensi TOEFL dapat terlaksana dengan baik dan lancar sesuai dengan rencana kegiatan yang telah direncanakan sebelumnya. Proses pelaksanaan kegiatan pengabdian masyarakat telah dilakukan dengan metode ceramah dan diskusi. Pada metode ceramah, salah satu tim menjelaskan tentang TOEFL (Test of English Foreign Language) dan Structure and Written Expression. Melalui kegiatan pemberian materi ini, para peserta kegiatan mendapatkan tambahan wawasan dan ilmu pengetahuan tentang TOEFL (Test of English Foreign Language). Materi yang disampaikan tentang "Tes TOEFL (Test of English Foreign Language), pengertian tes TOEFL, jenis tes TOEFL yang mencakup tes TOEFL PBT (Paper Based Test), CBT (Computer Based Test) dan IBT (Internet Based Test), jenis skill tes TOEFL, latihan soal tes TOEFL tiap skill, dan berbagai tips dan trik menjawab pertanyan tiap skill tes TOEFL". Pada metode diskusi, pembicara mengajak para peserta untuk saling berdiskusi tentang materi Tes TOEFL (Test of English Foreign Language) yang mencakup Structure and Written Expression. Pembicara memberikan tips dan trik menjawab berbagai soal tentang Structure \& Written Expression. Pada sesi ini, pembicara hanya fokus pada 5 materi dasar yakni, Subject-Verb Agreement, Object of Preposition, Appositives, Present Participle, dan Past Participle. Alasan hanya menyampaikan 5 materi adalah karena memperhitungkan alokasi waktu yang terbatas. Selain itu, peserta diminta untuk menjawab beberapa soal yang berkaitan dengan materi-materi yang telah disampaikan. Pembicara dan peserta saling berdiskusi jawaban-jawaban soal. Selanjutnya Pembicara memberikan tips dan trik menjawab berbagai soal. 
Pelatihan Penyelesaian Soal-Soal Structure dan Written Expression Berekuivalensi TOEFL pada Siswa SMK Telkom Pekanbaru

Qori Islami Aris, Essy Syam

Vol. 1, No. 2, Agustus 2021 hal. 109-115

DOI Artikel : 10.46306/jub.v1i2.21

Setelah melewati tahap demi tahap di atas, tim pengabdian memberikan post-test kepada siswa untuk mengidentifikasi sejauh mana kemampuan mereka dalam menyelesaikan soal-soal Structure \& Written Expression tersebut.

Hasil dari kegiatan ini adalah berupa peningkatan pemahaman dan kemampuan siswa dalam menyelesaikan soal-soal tentang Structure \& Written Expression. Hal tersebut ditunjukkan dengan peningkatan kemampuan peserta dalam menyelesaikan soal-soal tentang Structure \& Written Expression. Peningkatan pemahaman dan kemampuan siswa ditunjukkan pada tabel posttest berikut ini.

Tabel 3. Hasil Posttest

\begin{tabular}{|c|l|c|c|c|c|}
\hline \multirow{2}{*}{ No. Siswa } & \multirow{2}{*}{} & \multicolumn{4}{c|}{ Jawaban Siswa } \\
\cline { 3 - 6 } & & Benar & $\%$ & Salah & $\%$ \\
\hline I & Bunga Ramadani & 16 & $100 \%$ & 0 & $0 \%$ \\
\hline $\mathbf{2}$ & Dewi Ratna Sari & 16 & $100 \%$ & 0 & $0 \%$ \\
\hline $\mathbf{3}$ & Wafiq Azizah Putri & 16 & $100 \%$ & 0 & $0 \%$ \\
\hline $\mathbf{4}$ & Alya Rohalidini & 16 & $100 \%$ & 0 & $0 \%$ \\
\hline $\mathbf{5}$ & Jingga Lestari & 16 & $100 \%$ & 0 & $0 \%$ \\
\hline $\mathbf{6}$ & M. Ilham Maulana & 16 & $100 \%$ & 0 & $0 \%$ \\
\hline $\mathbf{7}$ & Teguh Afrinaldo & 16 & $100 \%$ & 0 & $0 \%$ \\
\hline $\mathbf{8}$ & Dio Wahyu & 16 & $100 \%$ & 0 & $0 \%$ \\
\hline $\mathbf{9}$ & Arip Mustofa & 16 & $100 \%$ & 0 & $0 \%$ \\
\hline I0 & Muhammad Alfian & 16 & $100 \%$ & 0 & $0 \%$ \\
\hline II & Nadia Tul Ullia & 16 & $100 \%$ & 0 & $0 \%$ \\
\hline I2 & Ariyan Pagera & 16 & $100 \%$ & 0 & $0 \%$ \\
\hline I3 & Rahma Ayu Vadylla & 16 & $100 \%$ & 0 & $0 \%$ \\
\hline I4 & Febrian Diyas & 16 & $100 \%$ & 0 & $0 \%$ \\
\hline I5 & Irma Gustini & 16 & $100 \%$ & 0 & $0 \%$ \\
\hline I6 & Sofi Adelia Putri & 16 & $100 \%$ & 0 & $0 \%$ \\
\hline Rata-Rata & \multicolumn{2}{|c|}{$\mathbf{1 0 0} \%$} & & $\mathbf{0} \%$ \\
\hline
\end{tabular}

Berdasarkan tabel di atas, dapat disimpulkan bahwa pengetahuan dan wawasan siswa mengalami peningkatan yang semula $51 \%$ menjadi $100 \%$.

\section{KESIMPULAN DAN SARAN}

Berdasarkan penjabaran sebelumnya, dapat disimpulkan beberapa hal mengenai kegiatan pengabdian ini. Hal-hal tersebut adalah sebagai berikut. Tahap-tahap yang dilaksanakan dalam proses pelatihan penyelesaian soal-soal Structure and Written Expression Berekuivalensi TOEFL, antara lain (I)Tahap Persiapan kegiatan pelatihan, pada tahap ini kegiatan pengabdian kepada masyarakat tentang pelatihan penyelesaian soal-soal Structure and Written Expression Berekuivalensi TOEFL untuk siswa-siswa SMK Telkom meliputi beberapa proses termasuk pengenalan, pemahaman latihan awal dan diskusi (2)Tahap pelatihan, pada tahap ini siswa diuji keterampilannya dalam penguasaan penyelesaian soalsoal Structure and Written Expression Berekuivalensi TOEFL. 
Pelatihan Penyelesaian Soal-Soal Structure dan Written Expression Berekuivalensi TOEFL pada Siswa SMK Telkom Pekanbaru

Qori Islami Aris, Essy Syam

Vol. 1, No. 2, Agustus 2021 hal. 109-115

DOI Artikel : 10.46306/jub.v1i2.21

Tes TOEFL (Test of English Foreign Language) merupakan salah satu tes kemampuan bahasa Inggris, oleh karena itu, perlunya mempersiapkan sebelum mengikuti tes TOEFL, misalkan dari segi kemampuan, siswa dapat mengikuti beberapa kursus untuk persiapan Tes TOEFL, atau belajar dari berbagai sumber misalkan dari referensi buku, Youtube dan sumber belajar lainnya.

\section{UCAPAN TERIMA KASIH}

Atas terlaksananya kegiatan pengabdian masyarakat ini, kami mengucapkan terimakasih kepada mitra, Kepala Sekolah SMK Telkom Pekanbaru dan Fakultas Ilmu Budaya Universitas Lancang Kuning Pekanbaru.

\section{DAFTAR PUSTAKA}

Phillips, Deborah. (200I). Longman Complete Course for the TOEFL Test. New York: Addison-Wesley Phillips, Deborah. (2004). Introductory Course for the TOEFL Test. New York: Longman.

Pyle, A. \& Michael. (2002). Cliffs, TOEFL Preparation Guide. India: Wiley Dreamtech. 